\title{
Legal Hermeneutic of Secondary Education in Indonesia: A Hermeneutical Approach
}

\author{
H. Syafa'at Anugrah Pradana \\ The State Institute for Islamic Studies of Parepare, South Sulawesi, Indonesia
}

\begin{abstract}
Legal hermeneutics of secondary education in Indonesia originates from the ideals of the founding fathers about how to educate the life of the nation. Indeed, the criteria for educating the life of nation started from the common sense of education, especially secondary education in Indonesia. The research was conducted using library research. Meanwhile, data were analyzed descriptively. The results show that education management is intended to ensuring public access to education services that are sufficient, equitable, and affordable; guarantee the quality and competitiveness of education. To get to a higher education program that is in line with the passion of each student, the initial step that must be taken is to improve the base of secondary education quality in accordance with the National Education Standards as issued by the National Education Standards Agency. Education should be a means of developing Indonesian people as a whole as quality subjects and have an impact on social change and a better society.
\end{abstract}

Keywords: Legal Hermeneutics; Secondary Education; National Education System

DOI: $10.7176 / \mathrm{EJBM} / 11-27-17$

Publication date:September $30^{\text {th }} 2019$

\section{Introduction}

Each country has different policies on the implementation of civic education. As an independent country, Indonesia administers Civic Education separately through a special subject under the name "citizenship education", ${ }_{1}^{1}$ while other countries, such as Malaysia, integrate this form of education into other subjects. It is apparent that legal education objectives can neither be separated from what is occurring in Indonesia nor the intentions of the government.

Legal education objectives in Indonesia have experienced a number of changes over time. According Juwana, ${ }^{2}$ these changes to the legal education objectives have tended to occur as there has been fundamental change of government, for example, an Indonesia that moved from being a colony to an independent state; an Indonesia in revolution to an Indonesia in the throes of development, and an Indonesia governed authoritatively to an Indonesia becoming increasingly democratic.

Historically, the term "Education" in Latin is called "Educare" which can be interpreted as to lead forth, ${ }^{3}$ while in Arabic is called "Tarbiyah". ${ }^{4}$ Education comes from the basic word "educate" which means to maintain and giving training. Both of these require teaching, guidance, and leadership about mind intelligence. The notion of education is the process of changing the attitudes and behavior of a person or group of people in an effort to mature humans through teaching and training. ${ }^{5}$

Ki Hadjar Dewantara (Bendara Raden Mas Soewardi Soeryaningrat) as cited in Romi Librayanto who argued that educational efforts were aimed at (a) the respectful of the mind, (b) the intelligence of the brain and (c) the health of the body. These three efforts will make human beings complete. Thus, education is an effort to form a whole person physically and mentally namely intelligent, healthy, and noble character. ${ }^{6}$ Furthermore, Ki Hadjar Dewantara asserted that educators must have the concept of 3 intact attitudes, namely "ing ngarsa sung tuladha, ing madya mangun karsa, dan tut wuri handayani”. It means that as educators must be able to become

\footnotetext{
${ }^{1}$ Nurdin, E. S. (2015). The Policies on Civic Education in Developing National Character in Indonesia. International Education Studies, 8(8), 199-209.

2 Juwana, H. (2006). Legal education reform in Indonesia. Asian Journal of Comparative Law, 1(1), $1932-0205$.

${ }^{3}$ Nurhadi, M. A. (2006). Desentralisasi dan Mahalnya Biaya Pendidikan. Jurnal Manajemen Pendidikan UNY. Vol. 2 No. 2 , 2006.

${ }^{4}$ Tarbiyah is an infinitive of "Rabba", teaching (ta'lim), education and teaching (tarbiyah wa ta'lim), Islamic education (tarbiyah islamiyah). This notion is different from Naquib Al Attas, an education thinker from Malaysia; he defines the meaning of Islamic education by contrasting the terms "Tarbiyah", "Ta'lim", and "Ta'dib". He refers to the educational meaning from the concept of $t a$ 'dib, which refers to the word $a d a b$ and its variations. As this thought, he formulates the definition of educating to form humans in placing their positions in accordance with the composition of society, behaving proportionally and in accordance with the science and technology. According to him, Islamic education is more quickly oriented towards $t a$ 'dib. While, tarbiyah in his view includes broader objects, not only limited to human education but also includes animals. Whereas, ta'dib only covering the notion of education for humans. See Achmadi. (2005). Ideologi Pendidikan Islam (Paradigma Humanisme Teosentris). Yogyakarta: Pustaka Pelajar. p. 26

${ }^{5}$ Fransisca, C. (2009). Peran Partisipasi Kegiatan di Alam Masa anak, Pendidikan dan Jenis Kelamin sebagai Moderasi Terhadap Perilaku Ramah Lingkungan. Thesis published. Magister of Psychology, Faculty of Psychology. Gadjah Mada University. p.33

${ }^{6}$ Librayanto, R. (2016). Sistem Norma Hukum Dalam Mewujudkan Rumusan Norma Hukum Yang Ideal. Dissertation. Hasanuddin University. p.172
} 
role models for their students, they are also able to maintain balance, can also encourage and provide motivation for their students. This educational trilogy is absorbed as the concept of "Pancasila" as Filosofische Grondslag. ${ }^{1}$ Some common features that can be summarized from several definitions of education include: ${ }^{2}$

a. Education has objectives to be achieved, i.e individuals whose abilities develop themselves so that it is useful for the benefit of life, both as an individual and as a citizen or citizen;

b. To achieve these objectives, education needs to make a deliberate and planned effort to choose the contents (materials), activity strategies, and appropriate assessment techniques;

c. These activities can be provided in the family, school and community environment, through formal and informal education.

In article 1 paragraph (1) of Act No. 20 of 2003 concerning the National Education System, Education is a deliberate and planned effort to create an atmosphere of learning and learning process so that students actively develop their potential to have religious spiritual strength, self-control, personality, intelligence, noble character, and skills needed by them, society, nation and State.

\section{An Overview of Secondary Education Management in Indonesia}

Education is the learning of knowledge, skills, and habits of a group of people inherited from one generation to the next through teaching, training, or research. It often takes place under the guidance of others, but is also selftaught.

The etymology of the word "education" itself comes from the Latin ducare, it means "guide, direct, or lead" and the prefix $e$, meaning "out". Thus, education means "leading out". Any experience that has a formative effect on the way of people to think, to feel, or to act can be considered as education. Education is generally divided into stages such as preschool, elementary school, secondary school and then college, university or internship. ${ }^{3}$ At the global level, article 13 of the International Covenant on Economic, Social and Cultural Rights recognizes right of everyone to education. ${ }^{4}$

According to Horton and Hunt, educational institutions relate to the manifest functions, as follows:

a) Prepare community members to make a living;

b) Developing individual talents for personal satisfaction and for the benefit of the community;

c) Preserve culture;

d) Inculcate skills necessary for participation in a democracy.

Meanwhile, in the view of David Popenoe, there are 4 (four) types of educational functions, as follows:

a) Cultural transmission;

b) Choose and teach social roles;

c) Ensure social integration;

d) School teaches personality patterns;

e) Source of social innovation

The line, level and types of education have been regulated in Chapter VI of the First Part of Act No. 20 of 2003 concerning the National Education System. The line of education consists of formal, non-formal and informal education which can complement and enrich each other. The level of formal education consists of basic, secondary and higher education. While, the type of education consists of general education, vocational, academic, professional, religious, and specialist.

The level of Early Childhood Education (or called PAUD) is held before entering basic education. This education informally is known as Kindergarten (TK - Taman Kanak-kanak), Raudatul Athfal (RA), or other equivalent. The level of basic education is an education that based the secondary education. This education informally is known as Elementary Schools (SD - Sekolah Dasar) and Madrasah Ibtidiyah (MI) or other equivalent and Junior High Schools (SMP - Sekolah Menengah Pertama) and Madrasah Tsanawiyah (MTs), or other equivalent.

The level of secondary education is a continuation of basic education. It consists of general and vocational secondary education. ${ }^{5}$ These educations informally are known as Senior High School (SMA - Sekolah Menengah Atas), Madrasah Aliyah (MA), Vocational High School (SMK - Sekolah Menengah Kejuruan), and Madrasah Aliyah Kejuruan (MAK), or other equivalent.

The level of higher education is an education level after secondary education which includes diploma, bachelor, master, specialist, and doctoral education programs organized by college/universities.

Non-formal education is held for citizens who need educational services that function as substitutes,

\footnotetext{
${ }^{1}$ Usfunan, Jimmy. Z. (2015). Pancasila as the Guidelines in the Legislation in Indonesia. Academic Research International, Vol. 6 (1): 272.

${ }^{2}$ M. Djumransjah. 2008. Op.Cit. p.28

${ }^{3}$ Dewey, J. (1944). Democracy and Education. The Free Press. pp.1-4

${ }^{4}$ ICESCR, Article 13.1

${ }^{5}$ See Article 18 paragraph (1) Act No. 20 of 2003 concerning National Education System.
} 
additions, and/or complementary formal education in the framework of supporting lifelong education. It serves to develop the potential of students with an emphasis on mastering knowledge and functional skills and developing professional attitudes and personalities. Non-formal education includes life skills education, early childhood education, youth education, women's empowerment education, literacy education, vocational education and job-training, equality education, and other education aimed at developing abilities of students.

The unit of non-formal education consists of course, training institutions, study groups, community learning centers and religious meeting or majelis taklim, as well as other equivalent units. Courses and training are held for people who need knowledge, skills, life skills, and attitudes to develop themselves, develop the profession, work, independent business, and/or continue their education to a higher level.

For early childhood education, non-formal education pathways can be held through Play Group, Child Care, or other equivalent forms. The activities of informal education as held by families and the environment in the form of independent learning activities. There are several examples of informal education pathways including character education, religious education, ethics education, courtesy education, moral education, and education on environmental socialization. For early childhood education in the informal education pathway can be done through family education or education organized by the environment.

Education management is the regulation of authority to conduct the national education system by the government, provincial government, district/city government, education providers established by the community and education units assures the education process can take place in accordance with the objectives of national education. ${ }^{1}$ Education management is conducted by the government, provincial government, district/city government, organizers of educational units established by the community, and educational units or programs.

Education management is aimed at ensuring community access to education services that are sufficient, equitable, and affordable; guarantee the quality and competitiveness of education and its relevance to the needs and/or conditions of the community; and ensuring the effectiveness, efficiency and accountability of education management.

Education management by the provincial government is conducted by the governor that responsible for managing the national education system in his area and formulating and establishing regional policies in the field of education in accordance with his authority.

The provincial government coordinates the implementation of education, the development of education personnel, and the provision of cross-regency/city education facilities for primary and secondary education. While, the district/city government manages basic and secondary education, as well as education units based on local excellence. ${ }^{2}$

Secondary education is divided into 2 (two) namely General and Vocational Secondary Education. However, General and Vocational Secondary Education have same functions, including: ${ }^{3}$

a. To enhance, living and practicing the values of faith, noble character and noble personality;

b. To enhance, living and practicing national values and the love of the homeland;

c. To study science and technology;

d. To increase sensitivity and ability to appreciate and express beauty and harmony;

e. To distribute talents and abilities in the field of sports, both for health and physical fitness and achievement; and

f. To increase physical and mental readiness to continue education to the higher education level and/or to live independently in the community.

\section{Legal Hermeneutics of Secondary Education in Indonesia}

The meaning of education includes 4 (four) fundamental things: ${ }^{4}$ First, essentially, education is a process of fostering human reason as main potential of humans as minded creatures. By the development of thought, humans are expected to increase their intelligence and thinking maturity, especially their intelligence in solving problems in their lives; Second, education is a skills training after humans obtain adequate knowledge from their thought. The intended skill is a particular object that helps human life because with these skills, humans seek sustenance and maintain their lives; Third, education is held in formal and non-formal institutions, as implemented in schools, families and the community; Last but not least, education aims to show communities who have a high culture and civilization with the main indicators of an increase in community intellectual intelligence, ethics and morals of a good and dignified society, and the formation of a noble personality.

Education as a social process that can affect individuals. It determines the way of life of a person, because there is a modification in person's outlook caused by the influence of interactions between intelligence, attention,

\footnotetext{
${ }^{1}$ See Article 1 paragraph (1) the Regulation of Minister No. 17 of 2010 concerning Management and Administration of Education.

${ }^{2}$ See Article 50 paragraph (5) Act No. 20 of 2003 concerning National Education System.

${ }^{3}$ See Article 76 paragraph (1) the Regulation of Minister No. 17 of 2010 concerning Management and Administration of Education.

${ }^{4}$ Basri, H. (2009). Filsafat Pendidikan Islam. Bandung: Pustaka Setia. p.56
} 
experience and so on. ${ }^{1}$ Hence, education is a two-way process that involves the giving of knowledge as an effort to give instructions and warnings, as well as the acquisition of knowledge to obtain piety, not to show self and arrogance (intellectual). ${ }^{2}$

Paulo Freire argued that education a process of humanizing humanity again. This idea comes from an analysis that social, political, economic, and cultural living systems make human experience a "dehumanization" process. Education as part of the system actually perpetuates the dehumanization process. In more detail, Freire explained the process of dehumanization by analyzing the consciousness or people's live view on them. Freire classifies human consciousness into: magical consciousness, naival consciousness, and critical consciousness. ${ }^{3}$

Education is a process of culture internalization into a person and making people to be polite. It is not only a means of knowledge transfer, but more broadly as a means of culture and distribution of values (acculturation and socialization). Learners or students must get an education that touches the basic dimensions of humanity. The human dimension includes 3 (three) fundamental things, as follows: ${ }^{4}$

1) Affective as reflected in the quality of faith, piety, noble character and superior personality, and esthetic competence;

2) Cognitive as reflected in thinking capacity and intellectual power to explore and develop and master science and technology; and

3) Psychomotor as reflected in the ability to develop technical skills, practical skills, and kinesthetic competence.

The function of education does not stop at individuals, but rather directly influences society. H.A.R. Tilaar, looks education as a means of social change. According to him, education is the key of all aspects of social, cultural, economic, and political life related to education. Social change can only occur through education, and increasing human capacity cannot through power, but education. While, humanistic psychologists like Maslow and Rogers argue that progressive education is calling for the re-structuring of society and nation. The development of education must produce a value system that is capable of driving positive changes in the life of the nation and state. ${ }^{5}$

This is in line with the opening of the 1945 Constitution, where one of the goals of the State is to educate the life of nation. Therefore, the function of education does not stop at individuals, but rather very broadly involving the whole community to be smart.

The philosophy of European education format can be a role model in developing education formats in Indonesia. The format of education in Europe namely:

a) $\quad$ Kindergarten $=$ Self-management;

b) Elementary School = Environmental exploration;

c) Junior High School = Finding and developing passion;

d) Senior High School = Designing a future career;

e) University = Building and maturing self-core skills.

If we focused on the format of secondary education (i.e Senior High School), then what must be considered is how to design the future careers of students. It aims to direct students, where they will be anchored. Therefore, this secondary education becomes a stepping stone of students towards their ideals and hopes.

Based on Act No. 20 of 2003 concerning the National Education System, education programs in higher education include:

a. Academic education (bachelor, master, doctoral);

b. Professional/specialist education; and

c. Vocational education (diploma).

To get to a higher education program that is suitable with the passion of each student, the initial step that must be taken is to improve the base of secondary education quality in accordance with the National Education Standards as issued by the National Education Standards Agency (hereinafter, BSNP). Hence, education should be a means of developing Indonesian people as a whole as quality subjects and have an impact on social change and a better society.

\section{Conclusion}

Education management is intended to ensuring public access to education services that are sufficient, equitable, and affordable; guarantee the quality and competitiveness of education and its relevance to the needs and/or conditions of the community; and ensuring the effectiveness, efficiency and accountability of education

\footnotetext{
${ }^{1}$ Azra, A., Afrianty, D., \& Hefner, R. W. (2007). Pesantren and Madrasa: Muslim schools and national ideals in Indonesia. Schooling Islam: The culture and politics of modern Muslim education, 172-98.

${ }^{2}$ Abd. A'la. No year. Pembaruan Pesantren. LKIS: Yogyakarta. p.37

${ }^{3}$ Librayanto. 2016. Op.Cit. pp.167-168

${ }^{4}$ Ibid.

${ }^{5}$ Ibid.
} 
management. To get to a higher education program that is in line with the passion of each student, the initial step that must be taken is to improve the base of secondary education quality in accordance with the National Education Standards as issued by the National Education Standards Agency (BSNP - Badan Standar Nasional Pendidikan). Education should be a means of developing Indonesian people as a whole as quality subjects and have an impact on social change and a better society.

\section{References}

Achmadi. (2005). Ideologi Pendidikan Islam (Paradigma Humanisme Teosentris). Yogyakarta: Pustaka Pelajar. Azra, A., Afrianty, D., \& Hefner, R. W. (2007). Pesantren and Madrasa: Muslim schools and national ideals in Indonesia. Schooling Islam: The culture and politics of modern Muslim education, 172-98.

Basri, H. (2009). Filsafat Pendidikan Islam. Bandung: Pustaka Setia.

Dewey, J. (1944). Democracy and Education. The Free Press.

Fransisca, C. (2009). Peran Partisipasi Kegiatan di Alam Masa anak, Pendidikan dan Jenis Kelamin sebagai Moderasi Terhadap Perilaku Ramah Lingkungan. Thesis published. Magister of Psychology, Faculty of Psychology. Gadjah Mada University.

Juwana, H. (2006). Legal education reform in Indonesia. Asian Journal of Comparative Law, 1(1), $1932-0205$.

Librayanto, R. (2016). Sistem Norma Hukum Dalam Mewujudkan Rumusan Norma Hukum Yang Ideal. Dissertation. Hasanuddin University.

Nurdin, E. S. (2015). The Policies on Civic Education in Developing National Character in Indonesia. International Education Studies, 8(8), 199-209.

Nurhadi, M. A. (2006). Desentralisasi dan Mahalnya Biaya Pendidikan. Jurnal Manajemen Pendidikan UNY. Vol. 2 No. 2.

Usfunan, Jimmy. Z. (2015). Pancasila as the Guidelines in the Legislation in Indonesia. Academic Research International, Vol. 6 (1): 272. 